\title{
Features of Computer-Based Decision Aids: Systematic Review, Thematic Synthesis, and Meta-Analyses
}

Ania Syrowatka ${ }^{1,2}, \mathrm{PhD}(\mathrm{c})$; Dörthe Krömker ${ }^{3}, \mathrm{PhD}$; Ari N Meguerditchian ${ }^{1,4,5}$, MD, MSc, FRCS, FACS; Robyn Tamblyn ${ }^{1,2,6}, \mathrm{PhD}$

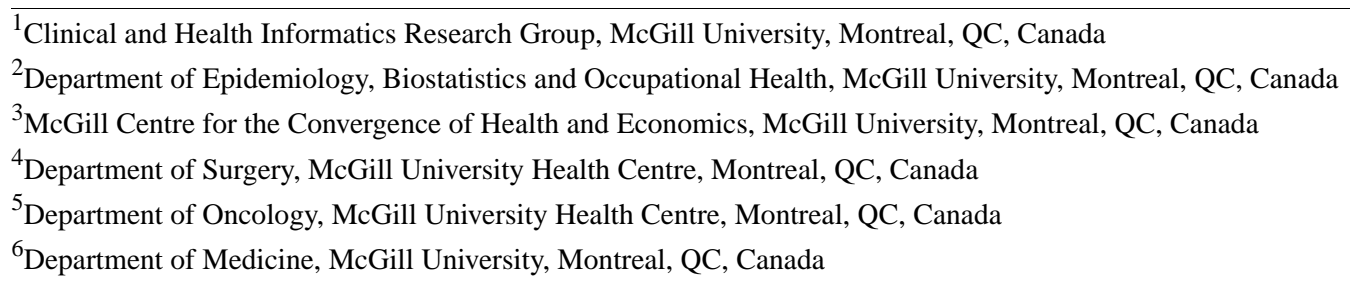

Corresponding Author:

Ania Syrowatka, $\mathrm{PhD}(\mathrm{c})$

Clinical and Health Informatics Research Group

McGill University

1140 Pine Avenue West

Montreal, QC, H3A1A3

Canada

Phone: 15149341934 ext 32999

Fax: 15148431551

Email: anna.syrowatka@mail.mcgill.ca

\section{Abstract}

Background: Patient information and education, such as decision aids, are gradually moving toward online, computer-based environments. Considerable research has been conducted to guide content and presentation of decision aids. However, given the relatively new shift to computer-based support, little attention has been given to how multimedia and interactivity can improve upon paper-based decision aids.

Objective: The first objective of this review was to summarize published literature into a proposed classification of features that have been integrated into computer-based decision aids. Building on this classification, the second objective was to assess whether integration of specific features was associated with higher-quality decision making.

Methods: Relevant studies were located by searching MEDLINE, Embase, CINAHL, and CENTRAL databases. The review identified studies that evaluated computer-based decision aids for adults faced with preference-sensitive medical decisions and reported quality of decision-making outcomes. A thematic synthesis was conducted to develop the classification of features. Subsequently, meta-analyses were conducted based on standardized mean differences (SMD) from randomized controlled trials (RCTs) that reported knowledge or decisional conflict. Further subgroup analyses compared pooled SMDs for decision aids that incorporated a specific feature to other computer-based decision aids that did not incorporate the feature, to assess whether specific features improved quality of decision making.

Results: Of 3541 unique publications, 58 studies met the target criteria and were included in the thematic synthesis. The synthesis identified six features: content control, tailoring, patient narratives, explicit values clarification, feedback, and social support. A subset of 26 RCTs from the thematic synthesis was used to conduct the meta-analyses. As expected, computer-based decision aids performed better than usual care or alternative aids; however, some features performed better than others. Integration of content control improved quality of decision making (SMD 0.59 vs 0.23 for knowledge; SMD 0.39 vs 0.29 for decisional conflict). In contrast, tailoring reduced quality of decision making (SMD 0.40 vs 0.71 for knowledge; SMD 0.25 vs 0.52 for decisional conflict). Similarly, patient narratives also reduced quality of decision making (SMD 0.43 vs 0.65 for knowledge; SMD 0.17 vs 0.46 for decisional conflict). Results were varied for different types of explicit values clarification, feedback, and social support.

Conclusions: Integration of media rich or interactive features into computer-based decision aids can improve quality of preference-sensitive decision making. However, this is an emerging field with limited evidence to guide use. The systematic review and thematic synthesis identified features that have been integrated into available computer-based decision aids, in an 
effort to facilitate reporting of these features and to promote integration of such features into decision aids. The meta-analyses and associated subgroup analyses provide preliminary evidence to support integration of specific features into future decision aids. Further research can focus on clarifying independent contributions of specific features through experimental designs and refining the designs of features to improve effectiveness.

(J Med Internet Res 2016;18(1):e20) doi: 10.2196/jmir.4982

\section{KEYWORDS}

computers; decision making; decision support systems, clinical; internet; medical informatics; patient participation; patient preference; patients

\section{Introduction}

Over the past decade, health care has shifted from paper-based practice to electronic health records [1]. Patient information and education, such as decision aids, are also gradually moving toward online, computer-based environments [2]. Decision aids are support tools intended to help patients engage in high-quality decision making for preference-sensitive decisions [3]. Preference-sensitive decisions are cases where there is more than one clinically appropriate option (eg, choosing between mastectomy and lumpectomy for treatment of breast cancer [4]), and as a result, depend on patients' values and preferences [3,5]. High-quality decision making occurs when well-informed patients consider evidence in the context of personal values and preferences to make a health decision. Decision aids have been shown to be effective for improving quality of decision making [3].

Considerable research has been conducted to guide content and presentation of decision aids [2,6-18]. In addition, the International Patient Decision Aid Standards Collaboration has established quality criteria for development and assessment of decision aids: (1) providing information in sufficient detail, (2) presenting probabilities in an unbiased manner, (3) including methods to clarify values and preferences, (4) providing structured guidance for deliberation and communication, (5) presenting information in a balanced manner, (6) using a systematic development process, (7) using up-to-date evidence, (8) disclosing conflicts of interest, (9) using plain language, and (10) ensuring that the decision is informed and values-based [6]. Additional quality criteria are recommended if the decision aid is delivered on the Internet or uses narratives. Further research has been conducted to expand upon these criteria. For example, risk communication literature builds on these standards by guiding how risk information (eg, probabilities) should be presented to facilitate high-quality decision making [19]. Similarly, research has been expanding around patient narratives $[20,21]$ and explicit methods to clarify values and preferences [22]. However, given the relatively new shift to computer-based support, little attention has been given to how multimedia and interactivity can improve upon paper-based decision aids [2].

Theory suggests that integration of media rich or interactive features into computer-based decision aids can have a positive impact on quality of decision making by engaging patients in decision making beyond traditional static approaches [2]. Therefore, this review focuses on features that can be implemented only on electronic platforms and are not feasible in paper-based decision aids. The first objective of this review was to summarize published literature into a proposed classification of features that have been integrated into computer-based decision aids. Building on this classification, the second objective was to assess whether integration of specific features was associated with higher-quality decision making.

\section{Methods}

\section{Study Selection}

\section{Search Strategy}

Four databases (MEDLINE, Embase, CINAHL, and CENTRAL) were searched for all relevant studies published from 1946-2013. Three main concepts of decision support, the patient, and computer were mapped to the most relevant controlled vocabulary using Medical Subject Headings (MeSH), and free-text terms were added where necessary. Full search strategies are outlined in Multimedia Appendix 1.

\section{Inclusion and Exclusion Criteria}

The review identified studies that evaluated computer-based decision aids for adults faced with a preference-sensitive medical decision (ie, treatment, risk management, screening, or prevention) and that reported at least one quality of decision-making outcome (ie, knowledge, decisional conflict [23], decisional certainty, satisfaction with decision making, or decisional self-efficacy). All comparative study designs were considered; eligible controls included alternative aids and no decision support (eg, usual care or pre-post assessments). Studies were excluded if the article did not report original research, was not published in the English language, or if the decision aid was intended for proxy decision making.

\section{Screening and Data Abstraction}

Screening of articles was completed in two stages. Articles were first screened for relevance based on the information provided in the title and abstract and were then evaluated for inclusion based on the full text. Two reviewers independently screened articles at each stage (AS and DK). Disagreements were resolved by discussion and consensus between the 2 reviewers. Overall kappa score was calculated to assess interrater reliability [24].

One reviewer completed data abstraction (AS), which focused on citation information, study design, decision context, interventions, controls (eg, usual care or alternative aids), components being tested, and quality of decision-making outcomes. If an article included in the review cited a 
development paper or webpage, then information from these sources was used to supplement data abstracted from the article.

\section{Thematic Synthesis}

All studies identified for the systematic review were included in the thematic analysis. Data abstracted from the articles was used to create a proposed classification of features that have been integrated into computer-based decision aids to date. The classification was developed based on logical groupings and informed by themes from decision aid literature [6,7].

Selection of groupings was completed by 1 reviewer (AS), guided by steps outlined by Thomas \& Harden for conducting thematic analysis: (1) line-by-line coding of articles to record components, (2) development of descriptive themes, and (3) creation of analytical themes [25]. Components were grouped into types (ie, descriptive themes) if the function of the components was similar; for example, components that improved navigation were grouped together. Similarly, types of components were judged to be similar and grouped into features (ie, analytical themes) if they served a similar purpose; for example, components that improved access to information were grouped together within the same feature. The proposed features classification went through an iterative process of review by co-authors and colleagues and was revised accordingly.

\section{Meta-Analyses}

Only randomized controlled trials (RCTs) that reported knowledge or decisional conflict were included in the quantitative synthesis. Decisional certainty, satisfaction with decision making, and decisional self-efficacy were not included due to the lower number of studies that reported these outcomes. The standardized mean difference (SMD; ie, Cohen's $d$ effect size) was calculated for each study [26]. For studies that reported multiple comparisons, only the comparison that tested the highest number of features was included in the analysis. If multiple measures were taken over time, only the first measure of knowledge or decisional conflict was included in the analysis. If studies reported more than one type of knowledge or more than one subscale of the decisional conflict scale (without reporting the total), then an average of the SMDs was calculated. For articles that did not provide sufficient information, study authors were contacted for additional information required to calculate the SMD.

The overall effect of computer-based decision aids was estimated by pooling the SMD of each study using Review Manager (version 5.3). Studies were pooled using inverse variance weighting and random effects models with $95 \%$ confidence intervals. Heterogeneity of pooled SMDs was assessed based on $\mathrm{I}^{2}$ statistics [27].

\section{Tests for Subgroup Differences}

Subgroup analyses were conducted to test whether specific features (or types of components) could explain some of the heterogeneity in the overall effect. Subgroup analyses compared pooled SMDs for decision aids that incorporated a specific feature to other computer-based decision aids that did not incorporate the feature to assess whether specific features were associated with improvements in quality of decision making. The Review Manager test for subgroup differences was used to assess statistical significance.

\section{Results}

\section{Study Selection}

The search identified 3541 eligible articles. The title and abstract screen retained 135 articles. Full text screening identified 58 studies that met the target criteria and were included in the thematic synthesis. The overall kappa score for screening was 0.60 , reflecting moderate interrater agreement [28]. A subset of 26 RCTs from the thematic synthesis was used to conduct the meta-analyses with 18 of the articles reporting knowledge and 21 of the articles reporting decisional conflict. A modified Preferred Reporting Items for Systematic Reviews and Meta-Analyses (PRISMA) flowchart is presented in Figure 1 [29], and studies included in the meta-analyses are indicated in Multimedia Appendix 2.

Data abstracted from articles are presented in Multimedia Appendix 2, including citation information, study design, decision context, interventions, controls, components being tested, and SMDs for RCTs reporting knowledge or decisional conflict [30-101]. The studies were published between 1996 and 2013 and came primarily from the United States (37/58, $64 \%)$, Canada $(7 / 58,12 \%)$, and the United Kingdom $(7 / 58$, $12 \%)$. The majority $(33 / 58,57 \%)$ of decision aids were developed for treatment decisions. The remaining decision aids were created for risk management $(6 / 58,10 \%)$, screening $(15 / 58$, $26 \%)$, and prevention decisions $(5 / 58,9 \%)$.

Studies assessed quality of decision making by measuring knowledge $(36 / 58,62 \%)$, decisional conflict $(30 / 58,52 \%)$, decisional certainty $(21 / 58,36 \%)$, satisfaction with decision making $(16 / 58,28 \%)$, and decisional self-efficacy $(7 / 58,12 \%)$. Studies compared computer-based decision aid performance to usual care $(18 / 58,31 \%)$, alternative aids $(29 / 58,50 \%)$, or based on pre-assessments $(14 / 58,24 \%)$. 
Figure 1. Modified PRISMA study selection flowchart.

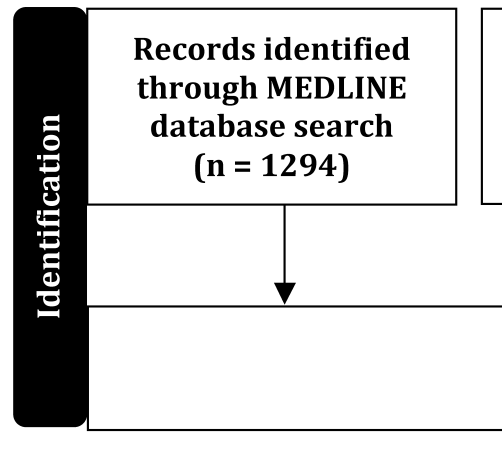

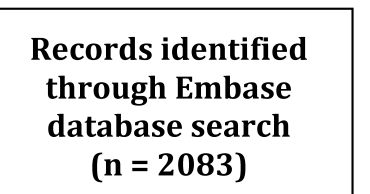

( $n=2083$ )

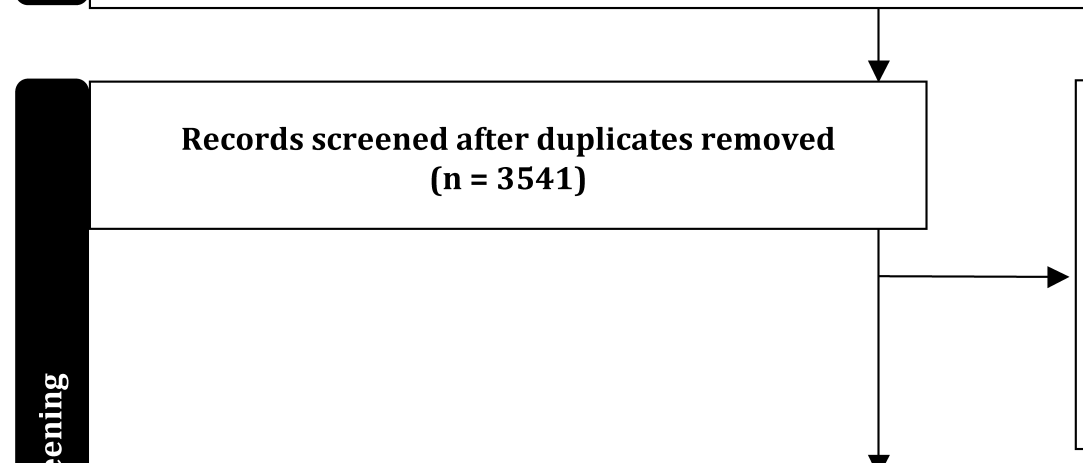

Records excluded, with reasons $(\mathrm{n}=3406)$

1. Not reported in English; 2. Not original research; 3. Not focused on patient or public decision making; 4 . Not focused on a medical decision; 5 . Not a decision aid; 6 . Not a comparative study design; 7. Not focused on adults; 8. Only usability or feasibility study; 9. Full-text not accessible

Full-text articles assessed for eligibility $(n=135)$

Studies included in thematic synthesis $(n=58)$

\section{Thematic Synthesis}

The thematic analysis identified six main features that have been integrated into computer-based decision aids: content control, tailoring, patient narratives, explicit values clarification, feedback, and social support. A proposed classification for these features and types of components is presented in Table 1. References to decision aids that implemented these features, as well as mode of presentation for each decision aid (eg, Web-based, videobooklet, CD-ROM) are provided in Multimedia Appendix 2, under columns titled "Features being tested" and "Interventions," respectively. 
Table 1. Proposed classification of features that have been integrated into computer-based decision aids (58 studies).

\begin{tabular}{|c|c|c|}
\hline Features & Types of components & Examples of components \\
\hline \multirow[t]{4}{*}{$\begin{array}{l}\text { Content control: Patient has control } \\
\text { over access to information }\end{array}$} & Navigation & $\begin{array}{l}\text { Menu bar, search function, television-like interface, touchscreen, help } \\
\text { menu }\end{array}$ \\
\hline & Clarity of information & $\begin{array}{l}\text { Glossary, information summaries, supplementary risk diagrams, } \\
\text { metaphors, narration }\end{array}$ \\
\hline & Optional information & "Learn more" sections for detailed information about topics of interes \\
\hline & Access to external resources & $\begin{array}{l}\text { Reference lists, links to summaries of recent studies or clinical practice } \\
\text { guidelines, developer contact information }\end{array}$ \\
\hline \multirow{3}{*}{$\begin{array}{l}\text { Tailoring: Patient receives personal- } \\
\text { ized information }\end{array}$} & Demographics & Patient age, gender, race/ethnicity, family history, health literacy \\
\hline & Clinical condition & $\begin{array}{l}\text { Specific diagnosis, stage of disease, comorbidities, current symptoms, } \\
\text { current medications, past treatment experience, eligibility for interven- } \\
\text { tions }\end{array}$ \\
\hline & Values, preferences, and beliefs & $\begin{array}{l}\text { Language, preferred role in decision making, stage of decision making } \\
\text { preference for colloquial vs technical terms, beliefs around efficacy } \\
\text { of screening or treatment }\end{array}$ \\
\hline
\end{tabular}

Knowledge deficits

Focus on information that is unclear or incorrect based on knowledge pre-tests

Patient narratives: Patient reflects on experiences of others

Explicit values clarification: Patien examines personal values and preferences

Feedback: Patient receives important information around decision making based on interactions with aid

Patient stories (focus on personal experiences)

Behavior modeling (focus on process of deliberation)

Decision points

Notebook

Weighting exercises

Trade-off exercises

Social matching

Personal reflection

Decision aid progress

Knowledge

Summary of preferences

Optimal choice

Decisional consistency

Summary of decision aid activity (usually printed)

Social support: Patient encouraged to involve others in decision-making

Community support

Integration of family

Facilitation of shared decision making Video of physician describing options and outcomes, video of physician encouraging patient to adhere to chosen option, video coaching to overcome physician communication barriers, recommended questions for physician consultations, copy of decision aid summary placed in patient chart, physician-specific modules 
The majority of studies included in the thematic analysis provided content control $(42 / 58,72 \%)$. Two-thirds tailored information to the patient $(38 / 58,66 \%)$, and almost half incorporated patient narratives $(28 / 58,48 \%)$. Over half of the studies provided explicit values clarification $(31 / 58,53 \%)$, feedback $(36 / 58,62 \%)$, or social support $(32 / 58,55 \%)$. One third of the studies incorporated five $(13 / 58,22 \%)$ or all six $(10 / 58,17 \%)$ of these features.

\section{Meta-Analyses}

Eighteen studies were included in the meta-analysis to assess whether or not use of computer-based decision aids improved knowledge. The studies included were published between 2001 and 2013. Most computer-based decision aids performed significantly better than usual care or alternative aid controls $(14 / 18,78 \%)$; the performance of the remaining decision aids was not significantly different from controls. Overall, computer-based decision aids were associated with significant improvements in knowledge with a pooled SMD of 0.54 (95\% CI $0.36-0.71 ; P<.001)$. A forest plot is presented in Figure 2.

We included 21 studies in the meta-analysis to assess whether or not use of computer-based decision aids improved decisional conflict. The studies included were published between 2002 and 2013. Most computer-based decision aids performed significantly better than usual care or alternative aid controls $(13 / 21,62 \%)$; the performance of the remaining decision aids was not significantly different from controls. Overall, computer-based decision aids were associated with significant improvements in decisional conflict with a pooled SMD of 0.35 $(95 \%$ CI $0.23-0.48 ; P<.001)$. A forest plot is presented in Figure 3.

Although computer-based decision aids performed significantly better than usual care or alternative aids, there was a high level of heterogeneity in study-level SMDs. The $\mathrm{I}^{2}$ statistics were $84 \%$ and $75 \%$ for knowledge and decisional conflict, respectively.

Figure 2. Forest plot of SMDs for improvements in knowledge (18 studies).

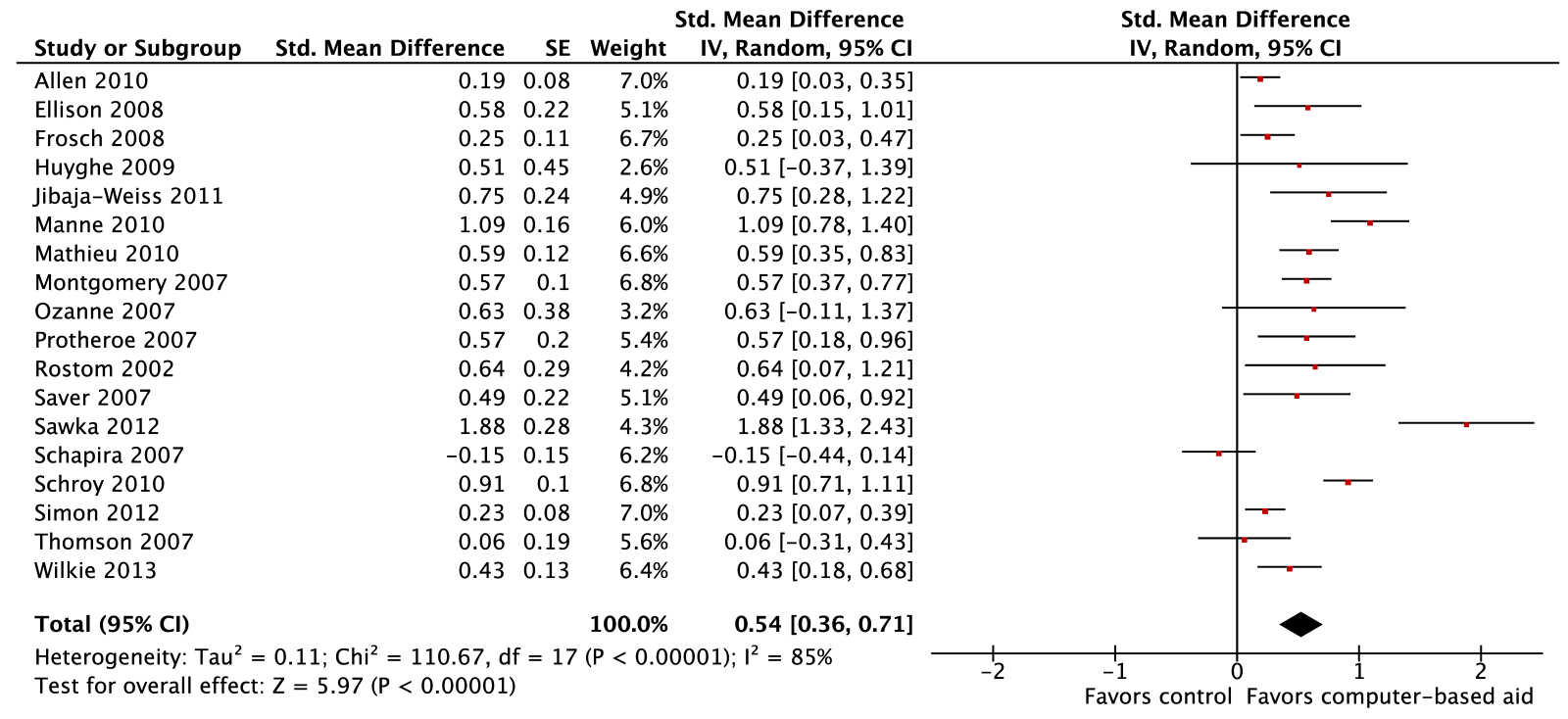


Figure 3. Forest plot of SMDs for improvements in decisional conflict (21 studies).

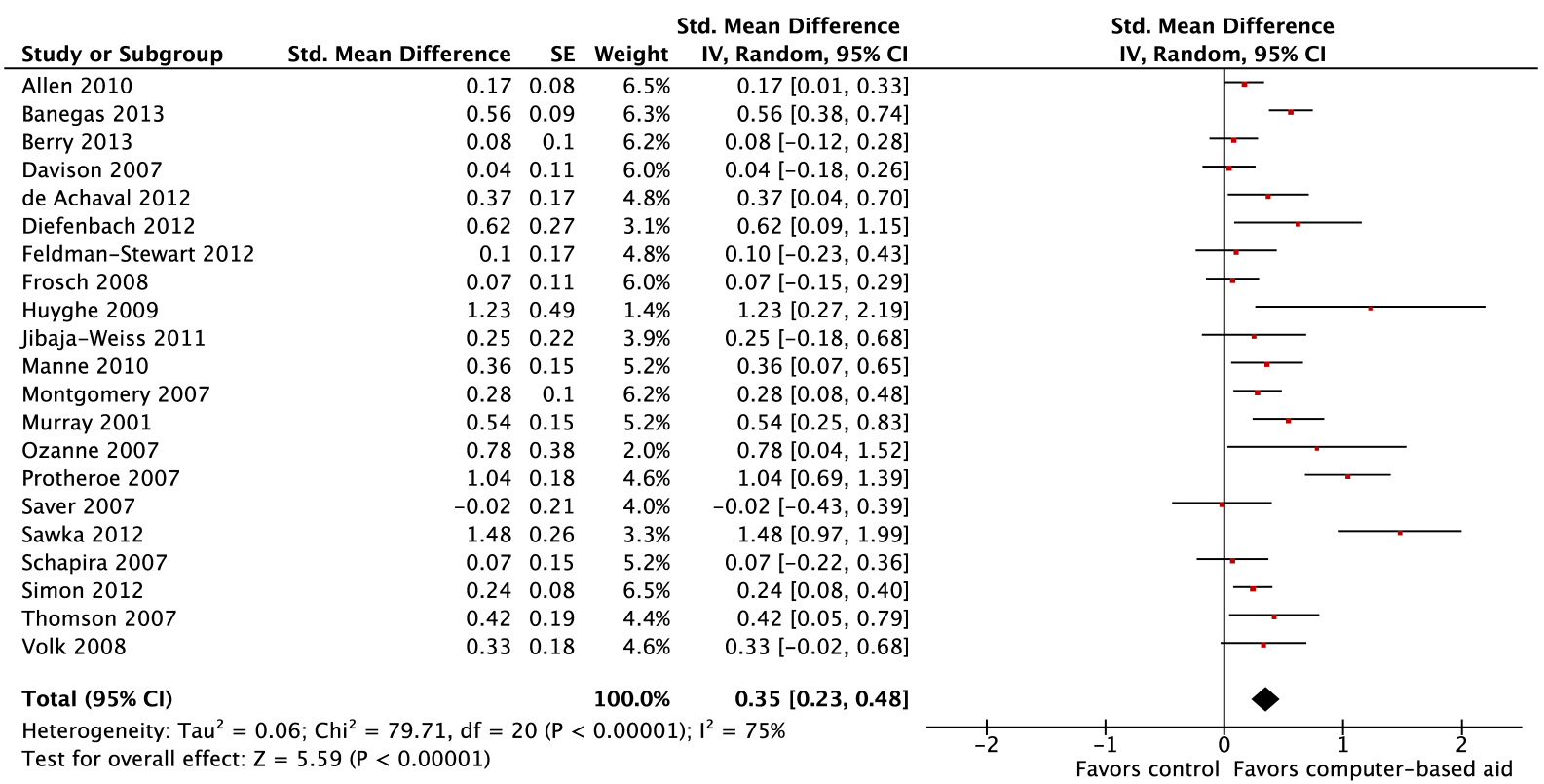

\section{Tests for Subgroup Differences}

The six features and associated types identified through the thematic analysis were used to inform subgroup analyses. The results are presented in Tables 2 (for knowledge) and 3 (for decisional conflict), which present and compare pooled SMDs for decision aids that include a specific feature (or type) to other computer-based decision aids that do not include the feature. The number of studies included in each subgroup and $P$ values associated with the Review Manager test for subgroup differences are also reported.

Overall, integration of content control was positively associated with quality of decision making, although the association was only significant for knowledge $(P=.008)$. However, specific types had differing effects. Knowledge and decisional conflict were negatively affected by offering navigation $(P=.56, P=.08$, respectively), whereas knowledge and decisional conflict both improved by providing clarity around evidence $(P=.03, P=.07$, respectively), optional in-depth information $(P=.05, P=.42$, respectively), or access to external resources $(P=.65, P=.15$, respectively).

Conversely, tailoring was negatively associated with knowledge and decisional conflict $(P=.08, P=.07$, respectively). This association was consistent across all types; both knowledge and decisional conflict were negatively affected by tailoring based on patient demographics ( $P=.07, P=.31$, respectively), clinical condition $(P=.06, P=.14$, respectively), or values, preferences, and beliefs $(P=.14, P=.02$, respectively).
Similarly, patient narratives reduced quality of decision making; however, the association was significant only for decisional conflict $(P=.005)$. Both knowledge and decisional conflict were negatively affected by presenting patient stories $(P=.54, P=.11$, respectively), or behavior modeling ( $P=.32, P=.01$, respectively).

Explicit values clarification reduced knowledge $(P=.42)$ but did not affect decisional conflict. However, effects varied for different types. Both knowledge and decisional conflict improved by integrating notebooks ( $P=.68, P=.56$, respectively), or trade-off exercises $(P=.84, P=.60$, respectively). Knowledge was reduced by providing weighting exercises $(P=.18)$ or social matching $(P=.47)$, with no effect on decisional conflict. Likewise, personal reflection reduced knowledge $(P=.47)$.

Overall, providing feedback was negatively associated with knowledge and decisional conflict ( $P=.40, P=.63$, respectively). Again, effects varied by type. Reporting progress through the decision aid improved decisional conflict $(P=.32)$. Likewise, both knowledge and decisional conflict improved by providing knowledge feedback $(P=.80, P=.07$, respectively). Providing a summary of preferences did not affect decisional conflict. Optimal choice feedback reduced knowledge $(P=.44)$, but improved decisional conflict $(P=.54)$. Both knowledge and decisional conflict were negatively affected by providing feedback around decisional consistency $(P<.001, P=.31$, respectively), or providing a summary of decision aid activity $(P=.35, P=.62$, respectively). 
Table 2. Number of studies and pooled SMDs for improvements in knowledge comparing decision aids including each feature to decision aids not including the feature (18 studies).

\begin{tabular}{|c|c|c|c|c|c|}
\hline Feature and types of components & Studies, $\mathrm{n}$ & $\begin{array}{l}\text { Feature included, } \\
\text { pooled SMD (95\% CI) }\end{array}$ & Studies, $\mathrm{n}$ & $\begin{array}{l}\text { Reference (no feature), } \\
\text { pooled SMD (95\% CI) }\end{array}$ & $P$ value $^{\mathrm{a}}$ \\
\hline Overall: Any feature & 18 & $0.54(0.36-0.71)$ & 0 & - & - \\
\hline Content control & 15 & $0.59(0.39-0.79)$ & 3 & $0.23(0.05-0.41)$ & .008 \\
\hline Navigation & 7 & $0.47(0.19-0.76)$ & 11 & $0.59(0.34-0.83)$ & .56 \\
\hline Clarity of information & 13 & $0.65(0.44-0.87)$ & 5 & $0.24(-0.05-0.54)$ & .03 \\
\hline Optional information & 7 & $0.76(0.42-1.09)$ & 11 & $0.38(0.21-0.54)$ & .05 \\
\hline Access to external resources & 6 & $0.63(0.15-1.10)$ & 12 & $0.51(0.32-0.70)$ & .65 \\
\hline Tailoring & 10 & $0.40(0.18-0.62)$ & 8 & $0.71(0.44-0.99)$ & .08 \\
\hline Demographics & 9 & $0.38(0.15-0.62)$ & 9 & $0.71(0.45-0.96)$ & .07 \\
\hline Clinical condition & 8 & $0.36(0.11-0.61)$ & 10 & $0.69(0.46-0.93)$ & .06 \\
\hline Values, preferences, and beliefs & 3 & $0.31(0.00-0.62)$ & 15 & $0.59(0.38-0.79)$ & .14 \\
\hline Knowledge deficits & 0 & - & 18 & $0.54(0.36-0.71)$ & - \\
\hline Patient narratives & 8 & $0.43(0.19-0.68)$ & 10 & $0.65(0.37-0.93)$ & .26 \\
\hline Patient stories & 7 & $0.47(0.20-0.75)$ & 11 & $0.59(0.34-0.83)$ & .54 \\
\hline Behavior modeling & 3 & $0.39(0.11-0.67)$ & 15 & $0.57(0.36-0.78)$ & .32 \\
\hline Explicit values clarification & 11 & $0.48(0.30-0.65)$ & 7 & $0.67(0.23-1.12)$ & .42 \\
\hline Decision points & 0 & - & 18 & $0.54(0.36-0.71)$ & - \\
\hline Notebook & 3 & $0.59(0.35-0.84)$ & 15 & $0.53(0.33-0.73)$ & .68 \\
\hline Weighting exercises & 8 & $0.41(0.24-0.58)$ & 10 & $0.65(0.34-0.95)$ & .18 \\
\hline Trade-off exercises & 3 & $0.58(0.12-1.04)$ & 15 & $0.53(0.33-0.72)$ & .84 \\
\hline Social matching & 1 & $0.43(0.18-0.68)$ & 17 & $0.55(0.36-0.73)$ & .47 \\
\hline Personal reflection & 1 & $0.43(0.18-0.68)$ & 17 & $0.55(0.36-0.73)$ & .47 \\
\hline Feedback & 8 & $0.46(0.27-0.64)$ & 10 & $0.60(0.31-0.89)$ & .40 \\
\hline Decision aid progress & 0 & - & 18 & $0.54(0.36-0.71)$ & - \\
\hline Knowledge & 2 & $0.60(0.12-1.08)$ & 16 & $0.53(0.35-0.72)$ & .80 \\
\hline Summary of preferences & 0 & - & 18 & $0.54(0.36-0.71)$ & - \\
\hline Optimal choice & 3 & $0.42(0.11-0.73)$ & 15 & $0.57(0.36-0.78)$ & .44 \\
\hline Decisional consistency & 2 & $0.17(0.03-0.31)$ & 16 & $0.60(0.40-0.79)$ & $<.001$ \\
\hline Summary of decision aid activity & 6 & $0.44(0.23-0.65)$ & 12 & $0.60(0.34-0.86)$ & .35 \\
\hline Social support & 10 & $0.58(0.32-0.84)$ & 8 & $0.50(0.23-0.76)$ & .67 \\
\hline Community support & 4 & $0.91(0.34-1.48)$ & 14 & $0.45(0.27-0.63)$ & .14 \\
\hline Integration of family & 3 & $0.50(0.29-0.72)$ & 15 & $0.54(0.34-0.74)$ & .82 \\
\hline Facilitation of shared decision making & 6 & $0.44(0.13-0.75)$ & 12 & $0.59(0.36-0.82)$ & .45 \\
\hline
\end{tabular}

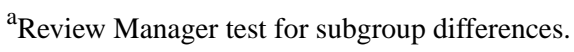


Table 3. Number of studies and pooled SMDs for improvements in decisional conflict comparing decision aids including each feature to decision aids not including the feature (21 studies).

\begin{tabular}{|c|c|c|c|c|c|}
\hline Feature and types of components & Studies, $\mathrm{n}$ & $\begin{array}{l}\text { Feature included, } \\
\text { pooled SMD }(95 \% \mathrm{CI})\end{array}$ & Studies, $\mathrm{n}$ & $\begin{array}{l}\text { Reference (no feature), } \\
\text { pooled SMD }(95 \% \mathrm{CI})\end{array}$ & $P$ value $^{\mathrm{a}}$ \\
\hline Overall: Any feature & 21 & $0.35(0.23-0.48)$ & 0 & - & - \\
\hline Content control & 14 & $0.39(0.23-0.56)$ & 7 & $0.29(0.08-0.49)$ & .42 \\
\hline Navigation & 8 & $0.22(0.10-0.34)$ & 13 & $0.42(0.23-0.60)$ & .08 \\
\hline Clarity of information & 12 & $0.46(0.28-0.65)$ & 9 & $0.23(0.07-0.40)$ & .07 \\
\hline Optional information & 6 & $0.44(0.20-0.68)$ & 15 & $0.32(0.17-0.47)$ & .42 \\
\hline Access to external resources & 5 & $0.72(0.12-1.33)$ & 16 & $0.28(0.18-0.37)$ & .15 \\
\hline Tailoring & 12 & $0.25(0.13-0.37)$ & 9 & $0.52(0.26-0.79)$ & .07 \\
\hline Demographics & 10 & $0.29(0.16-0.42)$ & 11 & $0.43(0.20-0.65)$ & .31 \\
\hline Clinical condition & 10 & $0.26(0.12-0.40)$ & 11 & $0.46(0.23-0.68)$ & .14 \\
\hline Values, preferences, and beliefs & 7 & $0.18(0.07-0.30)$ & 14 & $0.44(0.27-0.61)$ & .02 \\
\hline Knowledge deficits & 0 & - & 21 & $0.35(0.23-0.48)$ & - \\
\hline Patient narratives & 8 & $0.17(0.08-0.26)$ & 13 & $0.46(0.28-0.65)$ & .005 \\
\hline Patient stories & 5 & $0.20(0.03-0.38)$ & 16 & $0.39(0.24-0.54)$ & .11 \\
\hline Behavior modeling & 4 & $0.16(0.05-0.27)$ & 17 & $0.41(0.25-0.56)$ & .01 \\
\hline Explicit values clarification & 13 & $0.36(0.20-0.51)$ & 8 & $0.36(0.14-0.58)$ & .97 \\
\hline Decision points & 0 & - & 21 & $0.35(0.23-0.48)$ & - \\
\hline Notebook & 4 & $0.48(-0.02$ to 0.98$)$ & 17 & $0.32(0.20-0.44)$ & .56 \\
\hline Weighting exercises & 9 & $0.35(0.16-0.53)$ & 12 & $0.36(0.19-0.54)$ & .89 \\
\hline Trade-off exercises & 3 & $0.48(-0.08$ to 1.04$)$ & 18 & $0.33(0.20-0.45)$ & .60 \\
\hline Social matching & 1 & $0.33(-0.02$ to 0.68$)$ & 20 & $0.36(0.23-0.49)$ & .89 \\
\hline Personal reflection & 0 & - & 21 & $0.35(0.23-0.48)$ & - \\
\hline Feedback & 11 & $0.32(0.16-0.49)$ & 10 & $0.39(0.19-0.58)$ & .63 \\
\hline Decision aid progress & 1 & $0.62(0.09-1.15)$ & 20 & $0.35(0.22-0.47)$ & .32 \\
\hline Knowledge & 1 & $1.23(0.27-2.19)$ & 20 & $0.34(0.22-0.46)$ & .07 \\
\hline Summary of preferences & 1 & $0.37(0.04-0.70)$ & 20 & $0.35(0.23-0.48)$ & .93 \\
\hline Optimal choice & 4 & $0.45(0.09-0.81)$ & 17 & $0.33(0.19-0.46)$ & .54 \\
\hline Decisional consistency & 2 & $0.24(0.02-0.45)$ & 19 & $0.37(0.23-0.51)$ & .31 \\
\hline Summary of decision aid activity & 9 & $0.32(0.15-0.50)$ & 12 & $0.39(0.20-0.57)$ & .62 \\
\hline Social support & 11 & $0.38(0.19-0.57)$ & 10 & $0.34(0.17-0.51)$ & .75 \\
\hline Community support & 4 & $0.50(-0.08$ to 1.07$)$ & 17 & $0.33(0.21-0.45)$ & .58 \\
\hline Integration of family & 2 & $0.64(-0.30$ to 1.58$)$ & 19 & $0.35(0.22-0.47)$ & .54 \\
\hline Facilitation of shared decision making & 8 & $0.29(0.13-0.45)$ & 13 & $0.38(0.21-0.56)$ & .46 \\
\hline
\end{tabular}

${ }^{\mathrm{a}}$ Review Manager test for subgroup differences.

Social support improved knowledge $(P=.67)$ but did not affect decisional conflict. Both knowledge and decisional conflict improved by providing community support $(P=.14, P=.58$, respectively). Integration of family support did not affect knowledge but improved decisional conflict $(P=.54)$. Both knowledge and decisional conflict were negatively affected by facilitation of shared decision making $(P=.45, P=.46$, respectively).

\section{Discussion}

\section{Principal Results}

This review summarizes published literature into a proposed classification of features that have been integrated into computer-based decision aids. The thematic synthesis identified six main features of content control, tailoring, patient narratives, explicit values clarification, feedback, and social support. Building on this classification, meta-analyses with tests for 
subgroup differences were conducted to evaluate whether specific features improved quality of decision making. Overall, decision aids that integrated these features performed significantly better than usual care or alternative aids. The exploratory subgroup analyses rank-ordered the features. Overall, content control performed better than other features. Conversely, tailoring and patient narratives performed worse compared to other features. Results were varied for different types of explicit values clarification, feedback, and social support.

\section{Thematic Synthesis}

The proposed features classification is the first of its kind for decision aids. It serves two purposes: to provide the first step towards improving reporting of features that are integrated into computer-based decision aids and to promote use of such features in future decision aids. Currently, reporting standards for interventions are specific about the overarching goal of replicability; however, they offer little guidance around how to reach this goal. For example, the Consolidated Standards of Reporting Trials (CONSORT) statement simply states that authors should report sufficient information to ensure replicability, including detail around how and when interventions were administered [102]. The CONSORT statement extension for nonpharmacologic interventions builds on the former by stating that authors should report different components of interventions and procedures for tailoring interventions [103]. As a result of such vague recommendations, published descriptions of interventions, including decision aids, often do not provide sufficient information to guide replication [104]. In addition, lack of consistent language in reporting means that similar interventions can be reported using different descriptions, which can complicate evaluations to identify features that make interventions successful. Consequently, there has been a call for better reporting guidance [104]. To address such limitations in the field of behavior change, Abraham \& Michie developed a classification of active behavior change interventions [105]. Using the classification, a systematic review and meta-regression were conducted to evaluate behavior change interventions to promote healthy eating or physical activity [106]. The analysis highlighted "active ingredients" of successful interventions that may have otherwise been missed. Similarly, the classification proposed in this study can lead to better reporting of features that are integrated into computer-based decision aids, using consistent language. Improved reporting will build further evidence around the value of these features, which can guide integration of these features into future decision aids.

\section{Meta-Analyses}

As expected, computer-based decision aids were associated with significant improvements in knowledge and decisional conflict compared to usual care or alternative aids [3]. The subgroup analyses served as exploratory assessments of specific features and provided insight into which features perform better than others.

\section{Tests for Subgroup Differences}

\section{Content Control}

Overall, content control improved quality of decision making. All types of content control performed better than other features, with the exception of navigation. Content control is intended to provide patients with control over order, detail, and type of evidence presented [2]. The concept of content control is promising, considering that patients have different preferences for the amount of detail presented [107]. In addition, these preferences, often correlating with health literacy, can change over time, which highlights that a one-size-fits-all solution is not appropriate [107]. Ideally, content control should improve engagement, which has the potential to facilitate understanding and retention of evidence. In addition, providing the means to self-personalize content may promote autonomy and empower patients to take ownership over health care decisions.

Interestingly, navigation reduced quality of decision making compared to other features. Given that navigation is a foundational piece of computer-based interventions, this may represent a reporting bias. As a result of journal space limitations, navigation may have been underreported in exchange for reporting novel or impressive decision aid components. This relates back to the need for a classification to ensure that all features are reported; otherwise, important features may be overlooked as a result of biased evaluations.

\section{Tailoring}

Tailoring reduced quality of decision making, with all subgroups performing worse than other features. In general, tailoring is intended to translate evidence into patient-specific information to improve engagement. The effects of tailoring can be split into two categories: (1) effects on calculation of risk estimates, and (2) effects on presentation of information.

Tailoring can be used to frame evidence in terms of patient demographics or clinical condition to present only viable treatment options with more accurate estimates of associated risks and benefits. Ideally, this should provide a better understanding of personal situations and lead to high-quality decision making. However, evidence around the benefits of tailoring risk estimates is varied [13]. Tailoring may not be effective or may even be detrimental to decision making if personalized risk estimates are not considered appropriate by the patient [108]. Patients may distrust risk estimates if the estimates are not congruent with previous knowledge or if the risk calculations are not transparent or omit risk factors perceived as important [108]. Most of the tailoring incorporated in the decision aids included in this study was superficial and did not present risk information in the context of population risks. It is possible that the tailoring approaches were not developed appropriately and did not tailor sufficiently to be considered useful by the patients.

Tailoring can also be used to present evidence in terms of patient preferences or to address knowledge deficits, in an effort to facilitate understanding or to correct misinformation. However, this form of tailoring may limit the amount or type of evidence that is presented. For example, decision aids can be tailored to information-seeking style (ie, high or low levels of detail) [30] 
or information preferences (ie, focus on topics of interest) [31]. Such tailoring approaches may result in an incomplete or unbalanced presentation of evidence and unintentionally reduce quality of decision making. In fact, this form of tailoring could be considered the reverse of content control. Specifically, content control may promote patient autonomy by providing control over evidence reviewed, whereas tailoring employs a paternalistic model of presenting evidence, and as a result, may reduce autonomy.

\section{Patient Narratives}

Similarly, patient narratives reduced quality of decision making. Patient narratives are intended to provide insight into patient experiences and bring attention to important evidence to consider throughout the decision-making process. In addition, information presented through patient narratives is processed differently than written information and can improve understanding and retention of evidence [15,20,109]. However, narratives can unintentionally present biased or unbalanced information, which may result in lower-quality decision making $[2,20,110]$. To date, there is no consensus around the value of including patient narratives in decision aids $[2,15]$.

In this study, both patient stories and behavior modeling scenarios reduced quality of decision making. Shaffer and Zikmund-Fisher have developed a taxonomy for patient narratives outlining dimensions that are expected to impact decision making: (1) purpose of the narrative, (2) content of the narrative, and (3) evaluative valence (ie, tone of the narrative) [20]. This taxonomy highlights different types of content and proposes underlying mechanisms on how content might affect decision making for outcome, experience, and process narratives. Given that most articles simply reported inclusion of patient narratives, it is unclear whether the dimensions of purpose, content, and tone can explain the reduction in quality of decision making. However, based on this taxonomy, if the content of patient stories was disproportionally focused on adverse events, then risks associated with selecting a particular option may have been overrepresented. If anecdotal information presented through patient stories contradicts statistical data presented in the decision aid, then these conflicting messages may have reduced quality of decision making. Behavior modeling narratives (similar to process narratives described in the taxonomy) are intended to increase deliberation, by guiding the patient to consider or disregard specific factors related to decision making. However, if a narrative places more emphasis on factors not considered to be important or relevant to the patient, this could impede the decision-making process. This may even lead to lower-quality decision making by encouraging patients to focus on factors that are not in line with personal values or preferences. Further research can help determine the value of specific types of patient narratives, and what type of content and presentation facilitate higher-quality decision making.

The negative effects of tailoring and patient narratives on quality of decision making in decision aids were unexpected, considering the positive impact of tailoring and patient narratives when employed in behavior change interventions [111-113]. A potential reason for this may lie in the fundamental differences in purpose between decision aids and behavior change interventions. Specifically, behavior change interventions are intended to persuade the user to take up a specific health behavior, which is considered to be the best option [114]. However, this is not the purpose of decision aids, which are developed for preference-sensitive decisions where there is more than one clinically appropriate option [3]. The overarching goal of decision aids is to provide complete, balanced, and unbiased information to facilitate high-quality decision making. Tailoring and patient narratives, as implemented in the decision aids included in this systematic review, may have unintentionally presented superficial, unbalanced, or biased information, which may have reduced the quality of decision making. Further research needs to be conducted to refine the content and presentation of these two features to improve their effectiveness in decision aids.

\section{Explicit Values Clarification}

Specific types of explicit values clarification had a positive effect on quality of decision making. Explicit values clarification methods are intended to guide patients through specific tasks to identify personal values and preferences [14]. Few have been evaluated, and findings are mixed [14]. In this study, providing a "notebook" to record topics that were unclear or of concern was associated with higher-quality decision making. This device allowed patients to highlight areas where they needed more information, or where they needed to reflect more deeply on values and preferences. As a result, patients were more knowledgeable and had lower decisional conflict. Likewise, trade-off exercises (eg, rank-ordering all outcomes from most to least important) also improved quality of decision making. Such exercises provide a realistic approach to decision making, where the patient must consider and trade-off between risks and benefits of two or more options. In contrast, weighting exercises (eg, ranking each outcome on a scale of 1-10) can be inadequate if the patient ranks everything as equally important. In essence, trade-off exercises may help to better clarify issues around decision making.

\section{Feedback}

Specific types of feedback were also associated with improvements in quality of decision making. Feedback is intended to provide the patient with important information around decision making based on interactions with the decision aid. Progress through the decision aid and knowledge feedback both improved quality of decision making. Both are intended to ensure that the patient is well informed by confirming that all necessary information is reviewed by the patient and to correct misinformation, respectively. Summary of preferences, optimal choice, and decisional consistency are types of feedback that are specific to explicit values clarification methods. Summary of preferences provides feedback around how patients personally value risks and benefits integral to decision making. Optimal choice builds on summary of preferences, by suggesting which option is best based on patients' values and preferences, which had a positive effect on decisional conflict. Similarly, research has shown that providing implications of stated values (ie, optimal choice) may have a positive effect on decision making [22]. In contrast, decisional consistency reduced quality 
of decision making. This form of feedback elicits patients' initial decisions and reports whether or not the initial decisions are consistent with patients' values and preferences. This may lead to increased decisional conflict when the decision aid reports a lack of decisional consistency. This gives the impression that the initial decision was wrong and may elicit negative emotional responses from the patient.

\section{Social Support}

Specific types of social support improved quality of decision making. This feature is intended to reinforce that the patient is not alone in their experiences or decision making. Social support is a recurring theme throughout patient needs assessments for medical care [115-117], and patient decision aids specifically [118]. However, little guidance has been offered around what type of social supports can be integrated into decision aids and how. This review identified three types: community (ie, support from others faced with the same decision), family (ie, support from others affected by the specific decision), and clinician support (ie, facilitation of shared decision making). Community support improved knowledge and decisional conflict. Patients who had access to this type of support were likely able to have knowledge questions answered, as well as discuss how personal values and preferences fit into decision making. Integration of family support had positive effects on decisional conflict. Patients who had access to this type of support were likely able to better engage their partners and family members in the decision-making process and discuss values and preferences. Social support, specifically community and family support, seems to be promising but was limited by sample size in this study.

\section{Principles for Decision Aid Development and Future Directions}

Based on the study findings, content control should be integrated into decision aids to allow patients to select the order, level of detail, and type of information presented. This approach allows the patient to directly access topics of interest, view alternative presentations of information for clarity, and access optional information or external resources. However, to ensure balanced representation of all options, it is important to integrate safeguards to ensure that the patient reviews all necessary evidence (ie, not "optional" information) prior to making a final decision.

Tailoring, as currently developed and presented, should be used with caution, as it may reduce quality of decision making. Ineffective tailoring may have resulted from superficial or non-transparent tailoring, which patients did not believe reflected their true risk. Allowing patients to "self-tailor" through content control may be a viable option until effective strategies for tailoring information are established.

Patient narratives should also be used with caution, as they may reduce quality of decision making. Patient narratives may unintentionally present unbalanced or biased information, which may undermine statistical data presented in the decision aid or encourage patients to focus on factors that are not in line with personal values or preferences. Further research should focus on identifying types of narrative content and presentation that facilitate quality decision making.

Further research is also needed in the areas of feedback, explicit values clarification, and social support to guide future integration. There was substantial heterogeneity in effects between types of components within each of these features, which may reflect artificial grouping of components. In addition, small sample sizes limited appropriate assessments, with many components having been tested only in one decision aid, which limited guidance for integration of these features into decision aids.

\section{Limitations}

Studies included in the meta-analyses had a high level of heterogeneity with regard to patient populations, decision context, characteristics of the interventions, and components being tested, as well as choice of usual care or alternative aid controls. Studies were selected for inclusion based on testing a computer-based decision aid intervention, evaluating quality of decision making by measuring either knowledge or decisional conflict, and using an RCT design. For each subgroup analysis, decision aids that incorporated a specific feature (or type of component) were compared to decision aids that did not incorporate the feature. Effectively, this approach compared groupings of studies that tested various complex decision aids against very different control groups. Therefore, results from this study should be interpreted as "hypothesis-generating" and should be considered preliminary evidence to guide future work in this area.

Small numbers of studies incorporated certain types of components, which reduced the power to detect significant subgroup differences but also increased the probability of false positives. Nevertheless, subgroup analyses were conducted for all features and types of components for completion, and the number of studies in each subgroup was considered when interpreting the results.

Similarly, the study did not adjust for numerous comparisons generated through the subgroup analyses, which also increased the probability of false positives. However, given the exploratory nature of the study, such adjustments may not be necessary, since findings will require further research to establish independent contributions of each feature [27].

Given that the majority of decision aids incorporated multiple features, conducting subgroup analyses limited the capacity to disentangle the effects of specific features or to assess whether specific bundles of features were more effective for improving quality of decision making. Ideally, conducting a meta-regression, similar to the analysis described by Michie et al, would address these shortcomings [106]. However, a meta-regression was not considered appropriate for this study. The regression coefficients would have been unstable given the low number of studies ( 18 for knowledge and 21 for decisional conflict), and it would have been impossible to control for the substantial heterogeneity of decision aids included in the analysis. Therefore, straightforward exploratory subgroup analyses were selected as a viable alternative. 


\section{Conclusions}

Integration of media rich or interactive features into computer-based decision aids can improve quality of preference-sensitive decision making beyond traditional static approaches. However, this is an emerging field with limited evidence to guide implementation. The systematic review and thematic synthesis identified features used in available computer-based decision aids, in an effort to facilitate reporting of these features and to promote integration of such features into decision aids. The meta-analyses and associated subgroup analyses provide preliminary evidence to support integration of specific features into future decision aids. Further research can focus on clarifying independent contributions of specific features through experimental designs and refining the designs of features to improve effectiveness.

\section{Acknowledgments}

AS is supported by the Canadian Institutes of Health Research (CIHR) through the Frederick Banting and Charles Best Canada Graduate Scholarship Doctoral Research Award and by Knowledge Translation Canada through the Strategic Training Initiative in Health Research (STIHR) Fellowship.

The authors would like to thank Genevieve Gore for assistance in developing the search strategies for the systematic review. The authors would also like to thank investigators who provided additional information required to calculate SMDs for the meta-analyses and tests for subgroup differences.

\section{Authors' Contributions}

AS and RT were responsible for study conception and design; AS and DK acquired data; AS, AM, and RT analyzed and interpreted data; AS drafted the paper; and DK, AM, RT made critical revisions. All authors approved the final manuscript.

\section{Conflicts of Interest}

None declared.

\section{Multimedia Appendix 1}

Systematic review search strategies for MEDLINE, Embase, CINAHL, and CENTRAL.

[PDF File (Adobe PDF File), 360KB-Multimedia Appendix 1]

\section{Multimedia Appendix 2}

Information about studies included in the systematic review.

[PDF File (Adobe PDF File), 698KB-Multimedia Appendix 2]

\section{References}

1. Collier R. National Physician Survey: EMR use at 75\%. CMAJ 2015 Jan 6;187(1):E17-E18 [FREE Full text] [doi: 10.1503/cmaj.109-4957] [Medline: 25487665]

2. Hoffman AS, Volk RJ, Saarimaki A, Stirling C, Li LC, Härter M, et al. Delivering patient decision aids on the Internet: definitions, theories, current evidence, and emerging research areas. BMC Med Inform Decis Mak 2013;13 Suppl 2:S13 [FREE Full text] [doi: 10.1186/1472-6947-13-S2-S13] [Medline: 24625064]

3. Stacey D, Légaré F, Col NF, Bennett CL, Barry MJ, Eden KB, Wu Julie H C. Decision aids for people facing health treatment or screening decisions. Cochrane Database Syst Rev 2014;1:CD001431. [doi: 10.1002/14651858.CD001431.pub4] [Medline: $\underline{24470076]}$

4. Hawley ST. Involving patients in the decision-making process regarding breast cancer treatment: implications for surgery utilization. Womens Health (Lond Engl) 2010 Mar;6(2):161-164. [doi: 10.2217/whe.09.87] [Medline: 20187720]

5. Wennberg JE, Fisher ES, Skinner JS. Geography and the debate over Medicare reform. Health Aff (Millwood) 2002;Suppl Web Exclusives:W96-114 [FREE Full text] [Medline: 12703563]

6. Elwyn G, O'Connor A, Stacey D, Volk R, Edwards A, Coulter A, International Patient Decision Aids Standards (IPDAS) Collaboration. Developing a quality criteria framework for patient decision aids: online international Delphi consensus process. BMJ 2006 Aug 26;333(7565):417 [FREE Full text] [doi: 10.1136/bmj.38926.629329.AE] [Medline: 16908462]

7. Volk RJ, Llewellyn-Thomas H, Stacey D, Elwyn G. Ten years of the International Patient Decision Aid Standards Collaboration: evolution of the core dimensions for assessing the quality of patient decision aids. BMC Med Inform Decis Mak 2013;13 Suppl 2:S1 [FREE Full text] [doi: 10.1186/1472-6947-13-S2-S1] [Medline: 24624947]

8. Coulter A, Stilwell D, Kryworuchko J, Mullen PD, Ng CJ, van der Weijden T. A systematic development process for patient decision aids. BMC Med Inform Decis Mak 2013;13 Suppl 2:S2 [FREE Full text] [doi: 10.1186/1472-6947-13-S2-S2] [Medline: 24625093] 
9. Barry MJ, Chan E, Moulton B, Sah S, Simmons MB, Braddock C. Disclosing conflicts of interest in patient decision aids. BMC Med Inform Decis Mak 2013;13 Suppl 2:S3 [FREE Full text] [doi: 10.1186/1472-6947-13-S2-S3] [Medline: 24625114]

10. Feldman-Stewart D, O'Brien MA, Clayman ML, Davison BJ, Jimbo M, Labrecque M, et al. Providing information about options in patient decision aids. BMC Med Inform Decis Mak 2013;13 Suppl 2:S4 [FREE Full text] [doi: 10.1186/1472-6947-13-S2-S4] [Medline: 24625127]

11. Montori VM, LeBlanc A, Buchholz A, Stilwell DL, Tsapas A. Basing information on comprehensive, critically appraised, and up-to-date syntheses of the scientific evidence: a quality dimension of the International Patient Decision Aid Standards. BMC Med Inform Decis Mak 2013;13 Suppl 2:S5 [FREE Full text] [doi: 10.1186/1472-6947-13-S2-S5] [Medline: 24625191]

12. Abhyankar P, Volk RJ, Blumenthal-Barby J, Bravo P, Buchholz A, Ozanne E, et al. Balancing the presentation of information and options in patient decision aids: an updated review. BMC Med Inform Decis Mak 2013;13 Suppl 2:S6 [FREE Full text] [doi: 10.1186/1472-6947-13-S2-S6] [Medline: 24625214]

13. Trevena LJ, Zikmund-Fisher BJ, Edwards A, Gaissmaier W, Galesic M, Han P, et al. Presenting quantitative information about decision outcomes: a risk communication primer for patient decision aid developers. BMC Med Inform Decis Mak 2013;13 Suppl 2:S7 [FREE Full text] [doi: 10.1186/1472-6947-13-S2-S7] [Medline: 24625237]

14. Fagerlin A, Pignone M, Abhyankar P, Col N, Feldman-Stewart D, Gavaruzzi T, et al. Clarifying values: an updated review. BMC Med Inform Decis Mak 2013;13 Suppl 2:S8 [FREE Full text] [doi: 10.1186/1472-6947-13-S2-S8] [Medline: 24625261]

15. Bekker HL, Winterbottom AE, Butow P, Dillard AJ, Feldman-Stewart D, Fowler FJ, et al. Do personal stories make patient decision aids more effective? A critical review of theory and evidence. BMC Med Inform Decis Mak 2013;13 Suppl 2:S9 [FREE Full text] [doi: 10.1186/1472-6947-13-S2-S9] [Medline: 24625283]

16. McCaffery KJ, Holmes-Rovner M, Smith SK, Rovner D, Nutbeam D, Clayman ML, et al. Addressing health literacy in patient decision aids. BMC Med Inform Decis Mak 2013;13 Suppl 2:S10 [FREE Full text] [doi:

10.1186/1472-6947-13-S2-S10] [Medline: 24624970]

17. Stacey D, Kryworuchko J, Belkora J, Davison BJ, Durand M, Eden KB, et al. Coaching and guidance with patient decision aids: A review of theoretical and empirical evidence. BMC Med Inform Decis Mak 2013;13 Suppl 2:S11 [FREE Full text] [doi: 10.1186/1472-6947-13-S2-S11] [Medline: 24624995]

18. Sepucha KR, Borkhoff CM, Lally J, Levin CA, Matlock DD, Ng CJ, et al. Establishing the effectiveness of patient decision aids: key constructs and measurement instruments. BMC Med Inform Decis Mak 2013;13 Suppl 2:S12 [FREE Full text] [doi: 10.1186/1472-6947-13-S2-S12] [Medline: 24625035]

19. Zipkin DA, Umscheid CA, Keating NL, Allen E, Aung K, Beyth R, et al. Evidence-based risk communication: a systematic review. Ann Intern Med 2014 Aug 19;161(4):270-280. [doi: 10.7326/M14-0295] [Medline: 25133362]

20. Shaffer VA, Zikmund-Fisher BJ. All stories are not alike: a purpose-, content-, and valence-based taxonomy of patient narratives in decision aids. Med Decis Making 2013 Jan;33(1):4-13. [doi: 10.1177/0272989X12463266] [Medline: 23065418]

21. Shaffer VA, Hulsey L, Zikmund-Fisher BJ. The effects of process-focused versus experience-focused narratives in a breast cancer treatment decision task. Patient Educ Couns 2013 Nov;93(2):255-264. [doi: 10.1016/j.pec.2013.07.013] [Medline: $\underline{23962673]}$

22. Witteman HO, Scherer LD, Gavaruzzi T, Pieterse AH, Fuhrel-Forbis A, Exe N, et al. Supporting patient values: a systematic review of values clarification exercises. 2014 Presented at: 35th Annual Meeting for the Society for Medical Decision Making; October 22, 2013; Baltimore, Maryland.

23. O'Connor AM. Validation of a decisional conflict scale. Med Decis Making 1995;15(1):25-30. [Medline: 7898294]

24. Cohen J. A coefficient of agreement for nominal scales. Educ Psychol Meas 1960 Apr 01;20(1):37-46. [doi: 10.1177/001316446002000104]

25. Thomas J, Harden A. Methods for the thematic synthesis of qualitative research in systematic reviews. BMC Med Res Methodol 2008;8:45 [FREE Full text] [doi: 10.1186/1471-2288-8-45] [Medline: 18616818]

26. Cohen J. Statistical power analysis for the behavioral sciences, revised edition. New York, NY: Academic Press; 1977.

27. The Cochrane Collaboration. Cochrane handbook for systematic reviews of interventions, version 5.1.0. 2011. URL: http:/ /handbook.cochrane.org[WebCite Cache ID 6aXuMa5av]

28. Landis JR, Koch GG. The measurement of observer agreement for categorical data. Biometrics 1977 Mar;33(1):159-174. [Medline: $\underline{843571]}$

29. Moher D, Liberati A, Tetzlaff J, Altman DG. Preferred reporting items for systematic reviews and meta-analyses: the PRISMA statement. Ann Intern Med 2009 Aug 18;151(4):264-269, W64. [Medline: 19622511]

30. Diefenbach MA, Mohamed NE, Butz BP, Bar-Chama N, Stock R, Cesaretti J, et al. Acceptability and preliminary feasibility of an internet/CD-ROM-based education and decision program for early-stage prostate cancer patients: randomized pilot study. J Med Internet Res 2012;14(1):e6 [FREE Full text] [doi: 10.2196/jmir.1891] [Medline: 22246148]

31. Davison BJ, Goldenberg SL, Wiens KP, Gleave ME. Comparing a generic and individualized information decision support intervention for men newly diagnosed with localized prostate cancer. Cancer Nurs 2007;30(5):E7-15. [doi:

10.1097/01.NCC.0000290819.22195.d6] [Medline: 17876177]

32. Akl EA, Grant B, Guyatt GH, Montori VM, Schünemann HJ. A decision aid for COPD patients considering inhaled steroid therapy: development and before and after pilot testing. BMC Med Inform Decis Mak 2007;7:12 [FREE Full text] [doi: 10.1186/1472-6947-7-12] [Medline: 17504536 ] 
33. Berman L, Curry L, Goldberg C, Gusberg R, Fraenkel L. Pilot testing of a decision support tool for patients with abdominal aortic aneurysms. J Vasc Surg 2011 Feb;53(2):285-292.e1 [FREE Full text] [doi: 10.1016/j.jvs.2010.08.075] [Medline: 21067886]

34. Berry DL, Halpenny B, Hong F, Wolpin S, Lober WB, Russell KJ, et al. The Personal Patient Profile-Prostate decision support for men with localized prostate cancer: a multi-center randomized trial. Urol Oncol 2013 Oct;31(7):1012-1021 [FREE Full text] [doi: 10.1016/j.urolonc.2011.10.004] [Medline: 22153756]

35. Berry DL, Halpenny B, Wolpin S, Davison BJ, Ellis WJ, Lober WB, et al. Development and evaluation of the personal patient profile-prostate (P3P), a Web-based decision support system for men newly diagnosed with localized prostate cancer. J Med Internet Res 2010;12(4):e67 [FREE Full text] [doi: 10.2196/jmir.1576] [Medline: 21169159]

36. Brink SG, Birney AJ, McFarren AE. Charting your course: formative evaluation of a prostate cancer treatment decision aid. Int Electron J Health Educ 2000;3(1):44-54.

37. de Achaval S, Fraenkel L, Volk RJ, Cox V, Suarez-Almazor ME. Impact of educational and patient decision aids on decisional conflict associated with total knee arthroplasty. Arthritis Care Res (Hoboken) 2012 Feb;64(2):229-237 [FREE Full text] [doi: 10.1002/acr.20646] [Medline: 21954198]

38. Deyo RA, Cherkin DC, Weinstein J, Howe J, Ciol M, Mulley AG. Involving patients in clinical decisions: impact of an interactive video program on use of back surgery. Med Care 2000 Sep;38(9):959-969. [Medline: 10982117]

39. Spunt BS, Deyo RA, Taylor VM, Leek KM, Goldberg HI, Mulley AG. An interactive videodisc program for low back pain patients. Health Educ Res 1996 Dec;11(4):535-541 [FREE Full text] [Medline: 10163960]

40. Phelan EA, Deyo RA, Cherkin DC, Weinstein JN, Ciol MA, Kreuter W, et al. Helping patients decide about back surgery: a randomized trial of an interactive video program. Spine (Phila Pa 1976) 2001 Jan 15;26(2):206-211; discussion 212. [Medline: 11154542$]$

41. Diefenbach MA, Butz BP. A multimedia interactive education system for prostate cancer patients: development and preliminary evaluation. J Med Internet Res 2004 Jan 21;6(1):e3 [FREE Full text] [doi: 10.2196/jmir.6.1.e3] [Medline: 15111269]

42. Feldman-Stewart D, Tong C, Siemens R, Alibhai S, Pickles T, Robinson J, et al. The impact of explicit values clarification exercises in a patient decision aid emerges after the decision is actually made: evidence from a randomized controlled trial. Med Decis Making 2012;32(4):616-626. [doi: 10.1177/0272989X11434601] [Medline: 22287534]

43. Feldman-Stewart D, Brennenstuhl S, Brundage MD, Roques T. An explicit values clarification task: development and validation. Patient Educ Couns 2006 Nov;63(3):350-356. [doi: 10.1016/j.pec.2006.04.001] [Medline: 16860521]

44. Fraenkel L, Rabidou N, Wittink D, Fried T. Improving informed decision-making for patients with knee pain. J Rheumatol 2007 Sep;34(9):1894-1898. [Medline: 17696268]

45. Fraenkel L, Peters E, Charpentier P, Olsen B, Errante L, Schoen RT, et al. Decision tool to improve the quality of care in rheumatoid arthritis. Arthritis Care Res (Hoboken) 2012 Jul;64(7):977-985 [FREE Full text] [doi: 10.1002/acr.21657] [Medline: 22392766]

46. Heller L, Parker PA, Youssef A, Miller MJ. Interactive digital education aid in breast reconstruction. Plast Reconstr Surg 2008 Sep;122(3):717-724. [doi: 10.1097/PRS.0b013e318180ed06] [Medline: 18766034]

47. Jibaja-Weiss ML, Volk RJ, Friedman LC, Granchi TS, Neff NE, Spann SJ, et al. Preliminary testing of a just-in-time, user-defined values clarification exercise to aid lower literate women in making informed breast cancer treatment decisions. Health Expect 2006 Sep;9(3):218-231. [doi: 10.1111/j.1369-7625.2006.00386.x] [Medline: 16911136]

48. Jibaja-Weiss ML, Volk RJ, Granchi TS, Neff NE, Robinson EK, Spann SJ, et al. Entertainment education for breast cancer surgery decisions: a randomized trial among patients with low health literacy. Patient Educ Couns 2011 Jul;84(1):41-48. [doi: 10.1016/j.pec.2010.06.009] [Medline: 20609546]

49. Liao L, Jollis JG, DeLong ER, Peterson ED, Morris KG, Mark DB. Impact of an interactive video on decision making of patients with ischemic heart disease. J Gen Intern Med 1996 Jun;11(6):373-376. [Medline: 8803746]

50. Maslin AM, Baum M, Secker Walker J, A'Hern R, Prouse A. Shared decision-making using an interactive video disk system for women with early breast cancer. J Res Nurs 1998;3(6):444-454. [doi: 10.1177/174498719800300609]

51. Molenaar S, Sprangers MA, Rutgers EJ, Luiten EJ, Mulder J, Bossuyt PM, et al. Decision support for patients with early-stage breast cancer: effects of an interactive breast cancer CDROM on treatment decision, satisfaction, and quality of life. J Clin Oncol 2001 Mar 15;19(6):1676-1687. [Medline: 11250997]

52. Morgan MW, Deber RB, Llewellyn-Thomas HA, Gladstone P, Cusimano RJ, O'Rourke K, et al. Randomized, controlled trial of an interactive videodisc decision aid for patients with ischemic heart disease. J Gen Intern Med 2000 Oct;15(10):685-693 [FREE Full text] [Medline: 11089711]

53. Murray E, Davis H, Tai SS, Coulter A, Gray A, Haines A. Randomised controlled trial of an interactive multimedia decision aid on hormone replacement therapy in primary care. BMJ 2001 Sep 1;323(7311):490-493 [FREE Full text] [Medline: 11532844]

54. Piercy GB, Deber R, Trachtenberg J, Ramsey EW, Norman RW, Goldenberg SL, et al. Impact of a shared decision-making program on patients with benign prostatic hyperplasia. Urology 1999 May;53(5):913-920. [Medline: 10223483] 
55. Protheroe J, Bower P, Chew-Graham C, Peters TJ, Fahey T. Effectiveness of a computerized decision aid in primary care on decision making and quality of life in menorrhagia: results of the MENTIP randomized controlled trial. Med Decis Making 2007;27(5):575-584. [doi: 10.1177/0272989X07306785] [Medline: 17898242]

56. Rostom A, O'Connor A, Tugwell P, Wells G. A randomized trial of a computerized versus an audio-booklet decision aid for women considering post-menopausal hormone replacement therapy. Patient Educ Couns 2002 Jan;46(1):67-74. [Medline: 11804772]

57. Sawka AM, Straus S, Gafni A, Brierley JD, Tsang RW, Rotstein L, et al. How can we meet the information needs of patients with early stage papillary thyroid cancer considering radioactive iodine remnant ablation? Clin Endocrinol (Oxf) 2011 Apr;74(4):419-423 [FREE Full text] [doi: 10.1111/j.1365-2265.2010.03966.x] [Medline: 21198742]

58. Sawka AM, Straus S, Gafni A, Meiyappan S, O'Brien MA, Brierley JD, et al. A usability study of a computerized decision aid to help patients with early stage papillary thyroid carcinoma in decision-making on adjuvant radioactive iodine treatment. Patient Educ Couns 2011 Aug;84(2):e24-e27. [doi: 10.1016/j.pec.2010.07.038] [Medline: 20732775]

59. Sawka AM, Straus S, Rotstein L, Brierley JD, Tsang RW, Asa S, et al. Randomized controlled trial of a computerized decision aid on adjuvant radioactive iodine treatment for patients with early-stage papillary thyroid cancer. J Clin Oncol 2012 Aug 10;30(23):2906-2911 [FREE Full text] [doi: 10.1200/JCO.2011.41.2734] [Medline: 22753906]

60. Schapira MM, Gilligan MA, McAuliffe T, Garmon G, Carnes M, Nattinger AB. Decision-making at menopause: a randomized controlled trial of a computer-based hormone therapy decision-aid. Patient Educ Couns 2007 Jul;67(1-2):100-107. [doi: 10.1016/j.pec.2007.02.007] [Medline: 17400413]

61. Simon D, Kriston L, von Wolff A, Buchholz A, Vietor C, Hecke T, et al. Effectiveness of a web-based, individually tailored decision aid for depression or acute low back pain: a randomized controlled trial. Patient Educ Couns 2012 Jun;87(3):360-368. [doi: 10.1016/j.pec.2011.10.009] [Medline: 22154867]

62. Sivell S, Edwards A, Manstead ASR, Reed MWR, Caldon L, Collins K, et al. Increasing readiness to decide and strengthening behavioral intentions: evaluating the impact of a web-based patient decision aid for breast cancer treatment options (BresDex: www.bresdex.com). Patient Educ Couns 2012 Aug;88(2):209-217. [doi: 10.1016/j.pec.2012.03.012] [Medline: 22541508]

63. Sivell S, Marsh W, Edwards A, Manstead ASR, Clements A, Elwyn G, et al. Theory-based design and field-testing of an intervention to support women choosing surgery for breast cancer: BresDex. Patient Educ Couns 2012 Feb;86(2):179-188. [doi: 10.1016/j.pec.2011.04.014] [Medline: 21571485]

64. Taylor KL, Davis KM, Lamond T, Williams RM, Schwartz MD, Lawrence W, et al. Use and evaluation of a CD-ROM-based decision aid for prostate cancer treatment decisions. Behav Med 2010;36(4):130-140. [doi: 10.1080/08964289.2010.525263] [Medline: 21186436$]$

65. Thomson RG, Eccles MP, Steen IN, Greenaway J, Stobbart L, Murtagh MJ, et al. A patient decision aid to support shared decision-making on anti-thrombotic treatment of patients with atrial fibrillation: randomised controlled trial. Qual Saf Health Care 2007 Jun;16(3):216-223 [ FREE Full text] [doi: 10.1136/qshc.2006.018481] [Medline: 17545350]

66. Thomson R, Robinson A, Greenaway J, Lowe P. Development and description of a decision analysis based decision support tool for stroke prevention in atrial fibrillation. Qual Saf Health Care 2002 Mar;11(1):25-31 [FREE Full text] [Medline: $\underline{12078365]}$

67. van Til JA, Drossaert CHC, Renzenbrink GJ, Snoek GJ, Dijkstra E, Stiggelbout AM, et al. Feasibility of web-based decision aids in neurological patients. J Telemed Telecare 2010;16(1):48-52. [doi: 10.1258/jtt.2009.001012] [Medline: 20086268]

68. Hooker GW, Leventhal K, DeMarco T, Peshkin BN, Finch C, Wahl E, et al. Longitudinal changes in patient distress following interactive decision aid use among BRCA1/2 carriers: a randomized trial. Med Decis Making 2011;31(3):412-421 [FREE Full text] [doi: 10.1177/0272989X10381283] [Medline: 20876346]

69. Kaufman EM, Peshkin BN, Lawrence WF, Shelby R, Isaacs C, Brown K, et al. Development of an Interactive Decision Aid for Female BRCA1/BRCA2 Carriers. J Genet Couns 2003 Apr;12(2):109-129. [doi: 10.1023/A:1022698112236] [Medline: 26140844]

70. Huyghe E, Martinetti P, Sui D, Schover LR. Banking on Fatherhood: pilot studies of a computerized educational tool on sperm banking before cancer treatment. Psychooncology 2009 Sep;18(9):1011-1014 [FREE Full text] [doi: 10.1002/pon.1506] [Medline: $\underline{19061198]}$

71. Montgomery AA, Emmett CL, Fahey T, Jones C, Ricketts I, Patel RR, et al. Two decision aids for mode of delivery among women with previous caesarean section: randomised controlled trial. BMJ 2007 Jun 23;334(7607):1305 [FREE Full text] [doi: 10.1136/bmj.39217.671019.55] [Medline: 17540908]

72. Emmett CL, Murphy DJ, Patel RR, Fahey T, Jones C, Ricketts IW, et al. Decision-making about mode of delivery after previous caesarean section: development and piloting of two computer-based decision aids. Health Expect 2007 Jun;10(2):161-172. [doi: 10.1111/j.1369-7625.2006.00429.x] [Medline: 17524009 ]

73. Saver BG, Gustafson D, Taylor TR, Hawkins RP, Woods NF, Dinauer S, et al. A tale of two studies: the importance of setting, subjects and context in two randomized, controlled trials of a web-based decision support for perimenopausal and postmenopausal health decisions. Patient Educ Couns 2007 May;66(2):211-222. [doi: 10.1016/j.pec.2006.12.004] [Medline: $\underline{17317080}]$ 
74. Schwartz MD, Valdimarsdottir HB, DeMarco TA, Peshkin BN, Lawrence W, Rispoli J, et al. Randomized trial of a decision aid for BRCA1/BRCA2 mutation carriers: impact on measures of decision making and satisfaction. Health Psychol 2009 Jan;28(1):11-19 [FREE Full text] [doi: 10.1037/a0013147] [Medline: 19210013]

75. Wilkie DJ, Gallo AM, Yao Y, Molokie RE, Stahl C, Hershberger PE, et al. Reproductive health choices for young adults with sickle cell disease or trait: randomized controlled trial immediate posttest effects. Nurs Res 2013;62(5):352-361 [FREE Full text] [doi: 10.1097/NNR.0b013e3182a0316b] [Medline: 23995469]

76. Gallo AM, Wilkie DJ, Wang E, Labotka RJ, Molokie RE, Stahl C, et al. Evaluation of the SCKnowIQ tool and reproductive CHOICES intervention among young adults with sickle cell disease or sickle cell trait. Clin Nurs Res 2014 Aug;23(4):421-441 [FREE Full text] [doi: 10.1177/1054773813479377] [Medline: 23572406]

77. Allen JD, Mohllajee AP, Shelton RC, Drake BF, Mars DR. A computer-tailored intervention to promote informed decision making for prostate cancer screening among African American men. Am J Mens Health 2009 Dec;3(4):340-351 [FREE Full text] [doi: 10.1177/1557988308325460] [Medline: 19477736]

78. Allen JD, Othus MKD, Hart A, Tom L, Li Y, Berry D, et al. A randomized trial of a computer-tailored decision aid to improve prostate cancer screening decisions: results from the Take the Wheel trial. Cancer Epidemiol Biomarkers Prev 2010 Sep;19(9):2172-2186 [FREE Full text] [doi: 10.1158/1055-9965.EPI-09-0410] [Medline: 20716619]

79. Ellison GL, Weinrich SP, Lou M, Xu H, Powell IJ, Baquet CR. A randomized trial comparing web-based decision aids on prostate cancer knowledge for African-American men. J Natl Med Assoc 2008 Oct;100(10):1139-1145 [FREE Full text] [Medline: 18942274]

80. Evans R, Joseph-Williams N, Edwards A, Newcombe RG, Wright P, Kinnersley P, et al. Supporting informed decision making for prostate specific antigen (PSA) testing on the web: an online randomized controlled trial. J Med Internet Res 2010;12(3):e27 [FREE Full text] [doi: 10.2196/jmir.1305] [Medline: 20693148]

81. Frosch DL, Bhatnagar V, Tally S, Hamori CJ, Kaplan RM. Internet patient decision support: a randomized controlled trial comparing alternative approaches for men considering prostate cancer screening. Arch Intern Med 2008 Feb 25;168(4):363-369. [doi: 10.1001/archinternmed.2007.111] [Medline: 18299490$]$

82. Green MJ, Peterson SK, Baker MW, Harper GR, Friedman LC, Rubinstein WS, et al. Effect of a computer-based decision aid on knowledge, perceptions, and intentions about genetic testing for breast cancer susceptibility: a randomized controlled trial. JAMA 2004 Jul 28;292(4):442-452 [FREE Full text] [doi: 10.1001/jama.292.4.442] [Medline: 15280342]

83. Kuppermann M, Norton ME, Gates E, Gregorich SE, Learman LA, Nakagawa S, et al. Computerized prenatal genetic testing decision-assisting tool: a randomized controlled trial. Obstet Gynecol 2009 Jan;113(1):53-63. [doi: 10.1097/AOG.0b013e31818e7ec4] [Medline: $\underline{19104360]}$

84. Leung KY, Lee CP, Chan HY, Tang MHY, Lam YH, Lee A. Randomised trial comparing an interactive multimedia decision aid with a leaflet and a video to give information about prenatal screening for Down syndrome. Prenat Diagn 2004 Aug;24(8):613-618. [doi: 10.1002/pd.927] [Medline: 15305348]

85. Lindblom K, Gregory T, Wilson C, Flight IHK, Zajac I. The impact of computer self-efficacy, computer anxiety, and perceived usability and acceptability on the efficacy of a decision support tool for colorectal cancer screening. $\mathrm{J}$ Am Med Inform Assoc 2012;19(3):407-412 [FREE Full text] [doi: 10.1136/amiajnl-2011-000225] [Medline: 21857024]

86. Manne SL, Meropol NJ, Weinberg DS, Vig H, Ali-Khan CZ, Manning C, et al. Facilitating informed decisions regarding microsatellite instability testing among high-risk individuals diagnosed with colorectal cancer. J Clin Oncol 2010 Mar 10;28(8):1366-1372 [FREE Full text] [doi: 10.1200/JCO.2009.25.0399] [Medline: 20142594]

87. Mathieu E, Barratt AL, McGeechan K, Davey HM, Howard K, Houssami N. Helping women make choices about mammography screening: an online randomized trial of a decision aid for 40-year-old women. Patient Educ Couns 2010 Oct;81(1):63-72. [doi: 10.1016/j.pec.2010.01.001] [Medline: 20149953]

88. Australian screening mammography decision aid trial: a decision aid for women aged 40 thinking about starting mammography screening. 2003. Screening and Test Evaluation Program (STEP) at the University of Sydney URL: http:/ /www.mammogram.med.usyd.edu.au/ [accessed 2015-07-29] [WebCite Cache ID 6aOFhtKW3]

89. Ruffin MT, Fetters MD, Jimbo M. Preference-based electronic decision aid to promote colorectal cancer screening: results of a randomized controlled trial. Prev Med 2007 Oct;45(4):267-273. [doi: 10.1016/j.ypmed.2007.07.003] [Medline: $\underline{17689600]}$

90. Rupert DJ, Squiers LB, Renaud JM, Whitehead NS, Osborn RJ, Furberg RD, et al. Communicating risk of hereditary breast and ovarian cancer with an interactive decision support tool. Patient Educ Couns 2013 Aug;92(2):188-196. [doi: 10.1016/j.pec.2013.04.008] [Medline: 23664232]

91. Schroy PC, Emmons K, Peters E, Glick JT, Robinson PA, Lydotes MA, et al. The impact of a novel computer-based decision aid on shared decision making for colorectal cancer screening: a randomized trial. Med Decis Making 2011;31(1):93-107 [FREE Full text] [doi: 10.1177/0272989X10369007] [Medline: 20484090]

92. Siteman Cancer Center at Barnes-Jewish Hospital and Washington University School of Medicine. Your disease risk: the source on prevention. Cancer - colon cancer. 2013. URL: http://www.yourdiseaserisk.wustl.edu/YDRDefault. aspx?ScreenControl=YDRGeneral\&ScreenName=YDRcolon[WebCite Cache ID 6aOF8hynW] 
93. Volk RJ, Jibaja-Weiss ML, Hawley ST, Kneuper S, Spann SJ, Miles BJ, et al. Entertainment education for prostate cancer screening: a randomized trial among primary care patients with low health literacy. Patient Educ Couns 2008 Dec;73(3):482-489 [FREE Full text] [doi: 10.1016/j.pec.2008.07.033] [Medline: 18760888]

94. Banegas MP, McClure JB, Barlow WE, Ubel PA, Smith DM, Zikmund-Fisher BJ, et al. Results from a randomized trial of a web-based, tailored decision aid for women at high risk for breast cancer. Patient Educ Couns 2013 Jun;91(3):364-371 [FREE Full text] [doi: 10.1016/j.pec.2012.12.014] [Medline: 23395006]

95. Fagerlin A, Dillard AJ, Smith DM, Zikmund-Fisher BJ, Pitsch R, McClure JB, et al. Women's interest in taking tamoxifen and raloxifene for breast cancer prevention: response to a tailored decision aid. Breast Cancer Res Treat 2011 Jun;127(3):681-688 [FREE Full text] [doi: 10.1007/s10549-011-1450-1] [Medline: 21442198]

96. Ozanne EM, Annis C, Adduci K, Showstack J, Esserman L. Pilot trial of a computerized decision aid for breast cancer prevention. Breast J 2007;13(2):147-154. [doi: 10.1111/j.1524-4741.2007.00395.x] [Medline: 17319855]

97. Sheridan SL, Shadle J, Simpson RJ, Pignone MP. The impact of a decision aid about heart disease prevention on patients' discussions with their doctor and their plans for prevention: a pilot randomized trial. BMC Health Serv Res 2006;6:121 [FREE Full text] [doi: 10.1186/1472-6963-6-121] [Medline: 17005051]

98. Pignone M, Sheridan SL, Lee YZ, Kuo J, Phillips C, Mulrow C, et al. Heart to Heart: a computerized decision aid for assessment of coronary heart disease risk and the impact of risk-reduction interventions for primary prevention. Prev Cardiol 2004;7(1):26-33. [Medline: 15010625]

99. Sheridan SL, Griffith JM, Behrend L, Gizlice Z, Jianwen C, Pignone MP. Effect of adding a values clarification exercise to a decision aid on heart disease prevention: a randomized trial. Med Decis Making 2010;30(4):E28-E39 [FREE Full text] [doi: 10.1177/0272989X10369008] [Medline: 20484089]

100. Pignone MP, Sheridan SL, Communication for Health Applications and Interventions (CHAI) Core. Heart to heart: a tool for improving communication \& decision-making about heart disease prevention. URL: https://www.med-decisions.com/ h2hv2/ [accessed 2015-07-29] [WebCite Cache ID 6aOFcHHK9]

101. Sheridan SL, Draeger LB, Pignone MP, Keyserling TC, Simpson RJ, Rimer B, et al. A randomized trial of an intervention to improve use and adherence to effective coronary heart disease prevention strategies. BMC Health Serv Res 2011;11:331 [FREE Full text] [doi: 10.1186/1472-6963-11-331] [Medline: 22141447]

102. Schulz KF, Altman DG, Moher D. CONSORT 2010 Statement: updated guidelines for reporting parallel group randomised trials. BMC Med 2010;8:18 [FREE Full text] [doi: 10.1186/1741-7015-8-18] [Medline: 20334633]

103. Boutron I, Moher D, Altman DG, Schulz KF, Ravaud P. Extending the CONSORT statement to randomized trials of nonpharmacologic treatment: explanation and elaboration. Ann Intern Med 2008 Feb 19;148(4):295-309. [Medline: 18283207]

104. Glasziou P, Meats E, Heneghan C, Shepperd S. What is missing from descriptions of treatment in trials and reviews? BMJ 2008 Jun 28;336(7659):1472-1474 [FREE Full text] [doi: 10.1136/bmj.39590.732037.47] [Medline: $\underline{18583680}$ ]

105. Abraham C, Michie S. A taxonomy of behavior change techniques used in interventions. Health Psychol 2008 May;27(3):379-387. [doi: 10.1037/0278-6133.27.3.379] [Medline: 18624603]

106. Michie S, Abraham C, Whittington C, McAteer J, Gupta S. Effective techniques in healthy eating and physical activity interventions: a meta-regression. Health Psychol 2009 Nov;28(6):690-701. [doi: 10.1037/a0016136] [Medline: 19916637]

107. Matsuyama RK, Kuhn LA, Molisani A, Wilson-Genderson MC. Cancer patients' information needs the first nine months after diagnosis. Patient Educ Couns 2013 Jan;90(1):96-102. [doi: 10.1016/j.pec.2012.09.009] [Medline: 23058682]

108. Scherer LD, Ubel PA, McClure J, Greene SM, Alford SH, Holtzman L, et al. Belief in numbers: When and why women disbelieve tailored breast cancer risk statistics. Patient Educ Couns 2013 Aug;92(2):253-259 [FREE Full text] [doi: 10.1016/j.pec.2013.03.016] [Medline: 23623330]

109. Young LM, Anderson RP. The use of personal narrative in classroom case study analysis to improve long-term knowledge retention and cultivate professional qualities in allied health students. J Microbiol Biol Educ 2010;11(2):107-112 [FREE Full text] [doi: 10.1128/jmbe.v11i2.204] [Medline: 23653708]

110. Winterbottom A, Bekker HL, Conner M, Mooney A. Does narrative information bias individual's decision making? A systematic review. Soc Sci Med 2008 Dec;67(12):2079-2088. [doi: 10.1016/j.socscimed.2008.09.037] [Medline: 18951673]

111. Krebs P, Prochaska JO, Rossi JS. A meta-analysis of computer-tailored interventions for health behavior change. Prev Med 2010;51(3-4):214-221 [FREE Full text] [doi: 10.1016/j.ypmed.2010.06.004] [Medline: 20558196]

112. Lustria M, Noar SM, Cortese J, Van Stee SK, Glueckauf RL, Lee J. A meta-analysis of web-delivered tailored health behavior change interventions. J Health Commun 2013;18(9):1039-1069. [doi: 10.1080/10810730.2013.768727] [Medline: 23750972]

113. Hinyard LJ, Kreuter MW. Using narrative communication as a tool for health behavior change: a conceptual, theoretical, and empirical overview. Health Educ Behav 2007 Oct;34(5):777-792. [doi: 10.1177/1090198106291963] [Medline: 17200094]

114. Michie S, van Stralen M, West R. The behaviour change wheel: a new method for characterising and designing behaviour change interventions. Implement Sci 2011;6:42 [FREE Full text] [doi: 10.1186/1748-5908-6-42] [Medline: 21513547] 
115. Burg MA, Adorno G, Lopez E, Loerzel V, Stein K, Wallace C, et al. Current unmet needs of cancer survivors: analysis of open-ended responses to the American Cancer Society Study of Cancer Survivors II. Cancer 2015 Feb 15;121(4):623-630. [doi: 10.1002/cncr.28951] [Medline: 25581252]

116. van Walsem MR, Howe EI, Iversen K, Frich JC, Andelic N. Unmet needs for healthcare and social support services in patients with Huntington's disease: a cross-sectional population-based study. Orphanet J Rare Dis 2015;10:124 [FREE Full text] [doi: 10.1186/s13023-015-0324-8] [Medline: 26411462]

117. Song Y, Song H, Han H, Park S, Nam S, Kim MT. Unmet needs for social support and effects on diabetes self-care activities in Korean Americans with type 2 diabetes. Diabetes Educ 2012;38(1):77-85 [FREE Full text] [doi: 10.1177/0145721711432456] [Medline: 22222514]

118. Ng CJ, Mathers N, Bradley A, Colwell B. A 'combined framework' approach to developing a patient decision aid: the PANDAs model. BMC Health Serv Res 2014;14:503 [FREE Full text] [doi: 10.1186/s12913-014-0503-7] [Medline: $\underline{25341370]}$

\section{Abbreviations}

CONSORT: Consolidated Standards of Reporting Trials

MeSH: Medical Subject Headings

PRISMA: Preferred Reporting Items for Systematic Reviews and Meta-Analyses

RCT: randomized controlled trial

SMD: standardized mean difference

Edited by D Giordano; submitted 05.08.15; peer-reviewed by A Lau, $H$ Witteman; comments to author 14.09.15; revised version received 01.11.15; accepted 21.12.15; published 26.01 .16

Please cite as:

Syrowatka A, Krömker D, Meguerditchian AN, Tamblyn $R$

Features of Computer-Based Decision Aids: Systematic Review, Thematic Synthesis, and Meta-Analyses

J Med Internet Res 2016;18(1):e20

URL: http://www.jmir.org/2016/1/e20/

doi: $\underline{10.2196 / j m i r .4982}$

PMID: 26813512

(C)Ania Syrowatka, Dörthe Krömker, Ari N Meguerditchian, Robyn Tamblyn. Originally published in the Journal of Medical Internet Research (http://www.jmir.org), 26.01.2016. This is an open-access article distributed under the terms of the Creative Commons Attribution License (http://creativecommons.org/licenses/by/2.0/), which permits unrestricted use, distribution, and reproduction in any medium, provided the original work, first published in the Journal of Medical Internet Research, is properly cited. The complete bibliographic information, a link to the original publication on http://www.jmir.org/, as well as this copyright and license information must be included. 